\section{Economic appraisal of production flexibility in different regions of the Brazilian sugar and ethanol industry}

\author{
David Eduardo Lopez Pantoja ${ }^{1}$ \\ Carlos Patricio Mercado Samanez ${ }^{1}$ (in memoriam) \\ ${ }^{1}$ Pontifical Catholic University of Rio de Janeiro, Technical and Scientific Center, \\ Industrial Engineering Department, Rio de Janeiro, RJ, Brazil
}

\section{Javier Gutierrez Castro}

Federal University of Technology Paraná, Campus Ponta Grossa, Production Engineering Department, Ponta Grossa, PR, Brazil

\section{Fernando Antonio Lucena Aiube}

State University of Rio de Janeiro, Faculty of Economics, Quantitative Analysis Department, Rio de Janeiro, RJ, Brazil

\begin{abstract}
Purpose - The main goal of this study is to demonstrate the value of flexibility within sugar and ethanol production. We use real data for the Southeast and Northeast regions of Brazil, which are subject to different taxes rates.
\end{abstract}

Design/methodology/approach - The framework of this study is based on Real Options valuation. We valued the option to switch between sugar and ethanol production. The dynamics of prices was based on the recombinant trees of Nelson and Ramaswamy (1990) and on the bivariate trees of Hahn e Dyer (2011). Empirical data is from the Center of Advanced and Applied Economic Studies (CEPEA), ESALQ-USP, from May/2003 through July/2014. Prices were deflated using the Brazilian Price Index (IGP-DI), available at the Ipeadata site based on July/2014.

Findings - The results show that, in both regions, flexible systems have greater value than those that produce only one product. Southeast plants exhibit greater value added if compared with Northeast plants, not only because of lower taxes, but also due to higher productivity.

Originality/value - This paper quantifies value added by the flexible system in the production of sugar and ethanol in two Brazilian regions subject to different taxes. Moreover, it demonstrates that regulators can use policies and incentives to establish flexible plants. In this way, both producers and fiscal authorities will achieve greater gains.

Keywords - Agricultural commodities; flexible production; real options; recombinant binomial tree; bivariate binomial tree.
Received on $11 / 24 / 2015$

Approved on 06/07/2016

Responsible editor:

Prof. Dr. André Taue Saito

Evaluation process:

Double Blind Review

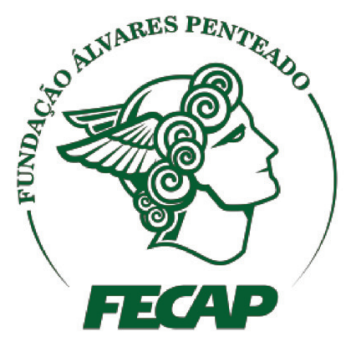

Review of Business Management

DOI: $10.7819 /$ rbgn.v18i60.2867 


\section{Introduction}

The development of the Brazilian ethanol industry is the best example in the world of the production and use of renewable energy on a large scale. In order to achieve this growth, Brazil carried out extensive technological advancement (technology generation, importation, adaptation and transfer) in agricultural and industrial production, in logistics and in end-uses over the last thirty years. It was also crucial to have specific legislation, as well as initial subsidies and permanent negotiation between the main stakeholders involved: ethanol producers, vehicle manufacturers, government regulatory sectors and the oil industry, in an intense and continuous learning process (Macedo, 2007). These facts led to the development of the ethanol industry, which, along with the technology of flexible production plants, give businessmen the option of producing two commodities: sugar and/or ethanol, depending on which is most profitable at a given time.

On the other hand, taxation plays an important role in ethanol and sugar prices across different Brazilian regions. We refer specifically to the Brazilian tax on the circulation of goods on interstate and county transportation and communications services [Imposto sobre Operaçóes relativas à Circulação de Mercadorias e sobre Prestaçóes de Serviços de Transporte Interestadual e Intermunicipal e de Comunicação, ICMS], which is a state tax, that is, only state governments and Brazil's federal district have the power to institute it. For example, according to the Sugarcane Industry Union [União da Indústria de Cana-deAçúcar, UNICA] - the largest local organization representing the sugar and ethanol industry in Brazil -, in 2013 the ICMS in São Paulo was $12 \%$, while in Pará it was $30 \%$.

Since producers have no control over commodity price fluctuations in the international market - a reference for prices in the local market -, there is a great deal of uncertainty regarding their future values; this uncertainty lends value to the flexibility that a plant can have to modify its production process and thus meet the demands of the commodity that is most profitable over a given period.

In real assets investment analysis under uncertainty, it is appropriate to use the Real Options (RO) theory, which takes into account the different managerial flexibilities that decisionmakers can use to change the course of a project while uncertainties are revealed. Thus, one can measure the value resulting from the flexibility of postponing, contracting, expanding, temporarily halting or abandoning a project, or of changing inputs and/or products. Flexible plants harbor within their facilities a system that allows for the production of one product or another. In this way, according to product prices, producers can choose to produce one product or another. Investing in a flexible system means being able to produce the most lucrative product in the future. The real options methodology quantifies the gains resulting from this flexibility.

Discrete modeling through the recombinant binomial tree developed by Cox, Ross and Rubinstein (1979) to evaluate financial options was extremely successful by discreetly approaching the model of Black and Scholes (1973); the latter is widely used to assess options whose underlying assets follow a Geometric Brownian Motion (GBM). Boyle (1988), on the other hand, introduced the bivariate binomial tree concept, which was followed by Nelson and Ramaswamy (1990), who presented a binomial sequence method in a comprehensive model that can be used in stochastic processes which follow either a GBM or a Mean Reversion Process (MRP). Hahn and Dyer (2011) modeled within discrete-time two-factor processes using bivariate binomial trees, by means of a two-dimensional tree format for the same problems analyzed by Schwartz and Smith (2000).

In this paper, we will calculate the value of switching between producing sugar (with ethanol as a byproduct) and ethanol, thus assessing to what extent this flexibility adds value to a project. We will evaluate two plants that only produce sugar 
or ethanol; next, we will compare their valuations to that of a flex plant that is capable of switching between producing two different commodities (sugar and ethanol). Analysis includes the Southeast and Northeast regions of Brazil, assuming that the main source of uncertainty in cash flows is the price of commodities. Given this premise, and after carrying out comparative analysis of the best fit to the behavior of historical price series between GBM and MRP, we chose to compute the values of the options using the MRP, following the methodologies of Nelson and Ramaswamy (1990) and Hahn and Dyer (2011).

This study was divided into seven sections. In section 1, we present the introduction and context of the research, defining its goal; in section 2, we address the alcohol and sugarcane industry in Brazil; in section 3, we define the real options of change and introduce the stochastic processes theory; in section 4, we develop the mean reversion process' binomial, recombinant binomial and bivariate modeling processes; in section 5, we calculate the value of the option of switching between ethanol and sugar; and in section 6 we present the conclusions of the research.

\section{Ethanol in brazil}

The first uses of ethanol as fuel in Brazil occurred around the end of the 1920s, when the Serra Grande Alagoas factory [Usina Serra Grande Alagoas, USGA], in the municipality of São José da Laje - in the Brazilian state of Alagoas -, produced this fuel for the first time. Meanwhile, Brazil's National Institute of Technology also produced alcohol for automobile propulsion. In 1931 , mixing $5 \%$ of ethanol into gasoline became compulsory in order to drain the Brazilian sugar industry's surplus production, and this percentage gradually increased. Over the following years, even during World War II, thousands of cars were running on alcohol in the Brazilian states of
Pernambuco and Minas Gerais, from sugarcane and cassava, respectively. However, production was weak and failed to compete with gasoline, more commonly used as fuel. Moreover, to the extent that the problems caused by economic recession began to decline, prices of oil and of its derivatives also begun to decrease; this eventually made the production of ethanol impossible at that time (Cavalcante, 2010).

Brazil's National Alcohol Program (Programa Nacional do Álcool, Proálcool), established on November 14, 1975 by federal government decree n. 76.593, aimed to focus efforts on the production of anhydrous fuel ethanol (AFE) from sugarcane, to be used in the mixture with gasoline in Otto cycle engines, at a $20 \%$ ratio. According to the program, the production of ethanol derived from sugarcane, cassava or any other input should be encouraged by expanding the supply of raw materials, with special emphasis on increasing agricultural production, on modernizing and expanding existing distilleries and on installing new production units, whether attached to plants or autonomous, and storage units (Nascimento, 2012).

Lima et al. (2013) mention that Proálcool is a milestone in the evolution of ethanol within the Brazilian market. The program can be divided into three stages: the first spans 1975-1979, following an increase in oil prices; the second, 1980-1990, the Proálcool apex; the third, 19912003, including program stagnation in the 1990 s and an unsuccessful attempt to reactivate Proálcool in 1996, followed by sugar and ethanol industry deregulation.

Flex fuel technology has given new impetus to the domestic consumption of alcohol. Car that can run both on gasoline and on alcohol - or on a mixture of the two fuels $=$ were introduced in Brazil in March 2003 and quickly seduced consumers. Currently, flex-fuel vehicles present higher market shares than those that run only on gasoline. 


\section{I Brazil and sugarcane}

Sugarcane is Brazil's third largest agricultural activity in terms of production area and gross produced value; soy and corn are the country's main crops. Sugarcane can be produced across almost all Brazilian regions. The largest producers are the states of São Paulo, Paraná, Triangulo Mineiro - in the state of Minas Gerais - and the Brazilian Northeast's Zona da Mata.

According to the second survey of 2013/2014 crops carried out by the Brazilian Ministry of Agriculture, Livestock and Supply [Ministério da Agricultura, Pecuária e Abastecimento, MAPA] in cooperation with the National Supply Company [Companhia Nacional de Abastecimento, CONAB] in August 2013, the area of sugarcane crops for sugar and cane production was estimated at 8,799,150 hectares, distributed across all producing states according to their characteristics. The state of São Paulo remains the largest producer, with $51.31 \%$ $(4,515,360$ hectares $)$ of planted area, followed by Minas Gerais, with $8.0 \%$ (781,920 hectares); Goiás, with 9.3\% (818,390 hectares); Paraná, with $7.04 \%$ (620,330 hectares); Mato Grosso do Sul, with 7.09\% (624,1 10 hectares); Alagoas, with 5.02\% (442,590 hectares); and Pernambuco, with $3.25 \%$ (286,030 hectares). In other Brazilian states these areas are smaller, with representations below 3.0\%.

\subsection{Ethanol prices}

The Brazilian sugar and ethanol industry faced major institutional changes with the deregulation process at the end of the 1990s. From the creation of Proálcool in 1975 on, the Brazil State was responsible for the planning and marketing of these products, as well as for regulating and mediating conflicts between agents. For a detailed description of the deregulation process, see Moraes (1999). For a review on the subject, see Barros and Moraes (2002), who report the deregulation process covering the period between March 1996 and February 1999.
According to Brazil's law n. 9.478/1997, later amended by law n. 9.990/2000, a price freedom regime was established across the chain of fuel production and marketing, distribution and retailing. This removed price tables, maximum and minimum values, government involvement in pricing or prior authorization to increase fuel prices. The regulator of activities within the oil and natural gas and biofuels field in Brazil is the National Petroleum Agency [Agência Nacional do Petróleo, ANP], which monitors prices through price surveys and fuel marketing margins (Nascimento, 2012).

We should highlight that, due to the field's deregulation, producers, anticipating problems that could arise, created in 1999 the São Paulo Council of Sugarcane, Sugar and Ethanol Producers [Conselho dos Produtores de Cana-deAçúcar, de Açúcar e Etanol do Estado de São Paulo, COSENCANA-SP], responsible for establishing the quality of sugarcane and its valuation. Thus, a mechanism for pricing the raw material used for producing sugar and ethanol was established; its use by agents was optional. Furthermore, the Council established a model contract to reduce supply procurement costs, making the relationship between sugarcane chain agents easier. Other states began to adapt it according to their regional characteristics (COSENCANA-SP http://www.consecana.com.br/).

\subsection{Ethanol taxation in Brazil}

According to Samanez et al. (2014), the final price of fuel is made up of four components: the first is the realization price, which is the selling price of goods at the plant or refinery without tax or shipping to fuel distributors; the second refers to taxes, and includes social integration program and civil service asset formation program federal taxes PIS/PASEP [Programa de Integração Social and Programa de Formaçâo do Patrimônio do Servidor Público] and the contribution to social security financing COFINS federal tax [Contribuição para Financiamento da Seguridade Social], the ICMS state tax on the circulation 
of goods and on interstate and intermunicipal transportation and communications services [Imposto sobre Operaçóes relativas à Circulação de Mercadorias e sobre Prestaçóes de Serviços de Transporte Interestadual e Intermunicipal e de Comunicação], which taxes producers and distributors, and the contribution for intervention in the economic domain CIDE tax [Contribuição de Intervenção no Domínio Econômico], belonging exclusively to the Brazilian State, which taxes producers; the third price component is logistics or freight costs in the different offices through which the product has to pass to reach the end point (plant-distributor-resale); and the fourth component is the profit margin divided between distributors and retailers.

Furthermore, Samanez et al. (2014) emphasize the importance of the ICMS, which is different for each state and for each type of fuel. These different taxes make ethanol prices vary across states and regions, rendering it more or less attractive to consumers, although its use is more beneficial to the environment than gasoline.

With the adoption of Brazil's provisional measure n. 613 on May 7, 2013 and its subsequent conversion into law n. 12.859 on 10 September 2013, the PIS/COFINS presumed credit was established for ethanol producers; it effectively zeroed the $\mathrm{R} \$ 0.12$ per liter rate for ethanol. Thus, there are no longer any federal taxes on ethanol. However, state taxes still exist; the most relevant one is ICMS.

Table 1 presents ICMS rates for different regions of Brazil. In it, one can distinguish that the Brazilian state with the smallest ICMS is São Paulo, at $12 \%$ over ethanol, and the state with the greatest ICMS is Pará, at 30\%.

Table 1 - ICMS rates across Brazilian regions in 2013

\begin{tabular}{llc}
\hline Region & States & ICMS (\%) 2013 \\
\hline \multirow{2}{*}{ North } & Rondônia, Acre, Amazonas, Roraima, Amapá, Tocantins & 25 \\
& Pará & 30 \\
\multirow{2}{*}{ Northeast } & Bahia & 19 \\
& Maranhão, Piauí, Ceará, Rio Grande do Norte, Paraíba, Pernambuco & 25 \\
\hline \multirow{3}{*}{ Southeast } & Alagoas, Sergipe & 27 \\
& Minas Gerais & 25 \\
\hline \multirow{2}{*}{ South } & Espírito Santo & 27 \\
\hline \multirow{2}{*}{ Midwest } & Rio de Janeiro & 24 \\
& São Paulo & 12 \\
\hline
\end{tabular}

Source: UNICA

The Brazilian Ministry of Mines and Energy's (MME) October 2013 bulletin shows that ANP authorized the operation of 365 ethanol plants, adding up to a total capacity of approximately 194 million liters of hydrous ethanol per day and of 99 million liters of anhydrous ethanol per day.
In the authorized capacity of ethanol production, the states of Sáo Paulo, Goiás and Minas Gerais represent approximately $70 \%$ of both anhydrous and hydrous ethanol. The state of São Paulo has the largest authorized capacity, representing around $50 \%$ of the total capacity, both of anhydrous ethanol and hydrous ethanol. 


\subsection{Literature review}

The literature of real options applied to the sugarcane industry in Brazil includes articles that highlight the use of flex vehicles, such as Samanez et al. (2014), and articles that deal with the production of alternative sources of energy, such as Bastian-Pinto et al. (2009).

On the other hand, empirical research referring to this field reveals analyses based on econometric models established in literature. In Melo and Sampaio (2016), the authors use VAR in the analysis of how ethanol and sugar offers respond to shocks on ethanol, sugar and gasoline prices. The results of the impulse-response functions indicate that producers respond more strongly to a change in the price of sugar than in ethanol.

Boff (2011) studies the relationship between ethanol/sugar and ethanol/gasoline prices in the retail market in the cities of Rio de Janeiro and São Paulo over the 2001-2010 period, through co-integration analysis (VAR-VECM). The author concludes that the model to explain the long-term behavior of the ethanol market in São Paulo is adequate. However, for the Rio de Janeiro market, the model is only partly suitable, as the study reports.

Balcombe and Rapsomanikis (2008) analyze the influence of the behavior of ethanol, sugar and oil prices on the Brazilian market. They use a bivariate error correction model that is best suited to the co-integration behavior of price series, which captures potential nonlinearities of errors when compared to long-run equilibrium. Models are estimated according to the Markov chain Monte Carlo (MCMC). They conclude that oil prices define sugar prices, and that nonlinearities were found in the adjustment of sugar and ethanol prices to oil prices. Moreover, the adjustment between ethanol and sugar is predominantly linear.

This study uses the real options methodology, analyzing the gains of plants that produce sugar and ethanol compared to those who do not have this flexibility. The real options methodology gained momentum in the 1990s, although its first article belongs to Tourinho (1979). It is appropriate for evaluating investments under uncertainty, such as uncertainty in future prices, costs or other variables involved in the cash flow. The classic texts on the subject are Dixit and Pindyck (1994) and Trigeorgis (1996).

The contribution of this study refers mainly to the analysis of gains arising from operational flexibility in two major Brazilian producing regions that process different loads and are subject to different taxes. Implications for sector policy regulators refer to the fact that flexibility, because of its greater gains, results in greater tax collection, thus making room for the creation of fiscal incentives, especially in places where rates are higher.

\section{Real options theory and stochastic processes followed by the prices of commodities}

The real options theory is a robust approach to investment analysis, in which the problem is dealt with as a case of optimization under uncertainty, seeking to maximize asset value through the optimum use of embedded options, subject to uncertainties and physical, legal and other restrictions. There are various types of real options, but in this article we will model and value the switch option, in which the plant owner can choose between producing sugar or ethanol, depending on the market price behavior of the two commodities. Valuing the option to switch means valuing the flexibility to change between various inputs and/or outputs in a production process in order to achieve the highest profit according to price fluctuations. As mentioned above, the details of the Real Options Theory can be found in Pindyck and Dixit (1994) and Trigeorgis (1996).

One often used way of modeling asset prices and, thus, of determining the value of a real option are stochastic processes. A stochastic process describes the behavior of a variable 
whose changes are uncertain over time, i.e., is a random process as a function of time. In the real options approach, to model and simulate the prices of assets in order to value the options embedded in the investment alternatives, three types of stochastic processes are generally used: Geometric Brownian Motion (GBM), Mean Reversion Motion (MRP) and MRP with Poisson jumps. MRP can be understood by considering that, in a competitive market, if the commodity price is far below the long-term average, supply decreases, forcing prices up due to a shortage of the product in the market; the same applies in the opposite direction. Given this assumption, the series of prices of a commodity has a natural tendency to revert to its long-term average, i.e., to the average of market balance, however slow this reversal process may be (the application of MRP in commodities can be seen in Schwartz (1997) and in Schwartz and Smith (2000)). As demonstrated by Aiube and Samanez (2014) and Samanez et al. (2014), MRP is the process that best describes commodity prices, and it will be used in this study to simulate ethanol and sugar prices.

\section{I Mean Reversion Motion}

Literature on finance generally adopts the mean reversion motion when modeling commodities. The motions of price increases and decreases, due to product shortage and oversupply, are the arguments on the side of economic intuition to justify the dynamics of reversion. Nevertheless, empirical studies can capture the reversion process. Bessembinder et al. (1995) show that, under equilibrium, the mean reversion property is detected for agribusiness, metals and energy commodities. For agricultural commodities and for oil, the reversion rate is significant and of high magnitude. Pindyck (1999) analyzes the behavior of energy commodities considering long historical series, and concludes that the data adheres to the reversion behavior. In this article, we follow the standards of literature and model the dynamics of ethanol and sugar prices using the mean reversion process. As is usual in articles of this nature, the adherence of historical prices to the reversion process was verified, as detailed in section 3.3.

The Mean Reversion Motion (MRP) is defined by the following stochastic differential equation:

$$
d X(t)=\eta(\bar{X}-X) d t+\sigma d z \quad \text { Eq. } 1
$$

Where: $X=$ stochastic variable; $\boldsymbol{\eta}=$ speed of the stochastic variable's mean reversion; $\sigma=$ volatility of the stochastic variable; $d z=$ increase or Wiener differential; $\bar{X}=$ long-term average of the stochastic variable; $d t=$ instantaneous time variation.

The conditional distribution of $X_{t}$ is normal, with average and variance given by Equations 2 and 3 (Dixit and Pindyck, 1994):

$$
\begin{array}{ll}
E\left[X_{t}\right]=\bar{X}+\left(X_{0}-\bar{X}\right) e^{-\eta t} & \text { Eq. } 2 \\
\operatorname{Var}\left[X_{t}\right]=\left(1-e^{-2 \eta t}\right) \sigma^{2} / 2 \eta & \text { Eq. } 3
\end{array}
$$

\subsection{Discretization and estimation of MRP parameters}

The discretized form of MRP is given by Equation 4.

$$
X_{t}=X_{t-1} e^{-\eta \Delta t}+\bar{X}\left(1-e^{-\eta \Delta t}\right)+\sigma \sqrt{\frac{1-e^{-2 \eta \Delta t}}{2 \eta}} N(0,1) \quad \text { Eq. } 4
$$

Where is the interval of time and $\mathrm{N}(0,1)$ is standard normal distribution.

So that MRP may be used to simulate prices, it is necessary to estimate the parameters present in its stochastic equation, that is, its volatility, its long-term average and the speed of its mean reversion. Thus, linear regression on the historic prices of commodities is carried out, according to Equation 5.

$$
\ln \left(x_{t}\right)-\ln \left(x_{t-1}\right)=a+(b-1) \ln \left(x_{t-1}\right)+\varepsilon_{t} \quad \text { Eq. } 5
$$


Where $x_{t}$ is the commodity price and $\varepsilon_{i} \sim N\left(0, \sigma_{\varepsilon}^{2}\right)$. Parameters $a$ and $b$ are obtained through linear regression.

As demonstrated in Dixit and Pindyck (1994), MRP parameters are calculated according to equations summarized in Table 2.

Table 2

\section{Summary of formulas to calculate MRP parameters}

\begin{tabular}{l|l}
\hline \multicolumn{1}{c}{ Parâmetro do MRM } & \multicolumn{1}{c}{ Equação } \\
\hline Velocidade de reversão & $\eta=-\ln (b) / \Delta t$ \\
Volatilidade & $\sigma=\sigma_{\varepsilon} \sqrt{2 \ln (b) /\left[\left(b^{2}-1\right) \Delta t\right]}$ \\
Média de longo prazo & $\bar{x}=\exp [-a /(b-1)]$ \\
\hline
\end{tabular}

\subsection{Determining MRP parameters based on historical series of prices}

The Southeast and Northeast are the biggest producers in Brazil. So, since they are representative of the industry, they are the regions to be examined in this article.

Price data was obtained from the Center for Advanced Studies in Economics (http:// www.cepea.esalq.usp.br), which is part of the Department of Economics, Management and Sociology at ESALQ-USP. The historical series (CEPEA, 2014) were analyzed in a monthly format between May 2003 and July 2014, containing 134 observations. Prices were deflated by the general price index of domestic supply IGP-DI [Índice Geral de Preços Disponibilidade Interna], provided by the Getúlio Vargas Foundation (FGV-IBRE, 2014) and available on a monthly basis in the site http://portalibre.fgv.br site, using July 2014 as reference.

Using Equation 5, the regression parameters of the historical price series were estimated. Table 3 shows the values that were found. Estimation results show that the $b$ parameter, related to the reversion process, is significant at the $1 \%$ level to ethanol, and at $5 \%$ for sugar. Thus, empirical data shows the adherence of the analyzed price series to MRP.
Table 3

Deflated ethanol and sugar prices regression parameters

\begin{tabular}{lcccc}
\hline \multirow{2}{*}{ Parameter } & \multicolumn{2}{c}{ Northeast } & \multicolumn{2}{c}{ Southeast } \\
\cline { 2 - 5 } & Ethanol & Sugar & Ethanol & Sugar \\
\hline $\mathrm{a}$ & $0.05502^{*}$ & $0.2649^{* *}$ & $0.03883^{*}$ & $0.2365^{* *}$ \\
$\mathrm{~b}$ & $0.86141^{*}$ & $0.9357^{* *}$ & $0.8344^{*}$ & $0.9409^{* *}$ \\
$\sigma_{\varepsilon}$ & $0.0687^{*}$ & $0.0837^{* *}$ & $0.1025^{*}$ & $0.09327^{* *}$ \\
(standard & & & & \\
deviation) & & & & \\
\hline
\end{tabular}

Note: $\left({ }^{*}\right),\left({ }^{* *}\right)$, represent significance levels of $1 \%$ and $5 \%$.

\section{Assessment through event trees}

Because they are easy to use, versatile and accurate, event trees are one of the most used methodologies for pricing options. Used for discrete-time models, event trees contain uncertainty nodes describing the possible behaviors of stochastic factors. In trees, the use of branches is flexible and can be adapted when changing the initial situation. Cox et al. (1979) were pioneers in the assessment of options using recombinant binomial trees, showing that in this type of tree the value of a European-type option converges to the value given by the formula of Black and Scholes (1973). However, Boyle (1988) was the first one to use the approach of Cox et al. (1979) in a trinomial tree to assess options with a single underlying asset. By using stochastic processes with two factors, the author introduces a new concept, that of bivariate trees. Subsequently, using the same approach, Nelson and Ramaswamy (1990) developed a model for assets that follow both GBM and MRP.

To model the price of the commodity and to calculate the abandonment option of an oil well, Hahn (2005), following the basic structure proposed by Nelson and Ramaswamy (1990), used a model with two factors. Following this same approach, Bastian-Pinto et al. (2009) worked with the price of two commodities, sugar and ethanol, using as a stochastic process one MRP to assess an input switch option, thus developing a quadrinomial tree. Hahn and Dyer 
(2011) worked with stochastic processes with two factors and bivariate binomial trees for discretetime modeling, using a two-dimensional tree format. In Brazil, Samanez and Costa (2014) assessed swing type options in natural gas market contracts, using bivariate binomial trees.

\section{I Recombinant binomial trees}

Nelson and Ramaswamy (1990) propose a general method to develop recombinant binomial trees. The problem is to find a binomial sequence that converges to the following stochastic differential equation:

$$
d X(t)=\alpha(X, t) d t+\sigma(X, t) d z \quad \text { Eq. } 6
$$

Where $X(t)$ is the natural logarithm of asset price at instant $t$, that is, $X(t)=\ln \left(x_{t}\right) ; \alpha(X, t)$; $\sigma(X, t)$ and are the process growth rate (drift) and the standard deviation, respectively, and $d z$ is the standard Wiener increase.

To solve this problem, the authors proposed a simple binomial sequence with $n$ periods of $\Delta t$ duration. This sequence is given by: $X_{t}^{+}=X+\sqrt{\Delta t} \sigma(X, t)$ is the motion upwards (up); $X_{t}^{-}=X-\sqrt{\Delta t} \sigma(X, t)$ is the motion downwards (down);

$p_{t}=\frac{1}{2}+\frac{1}{2} \sqrt{\Delta t} \alpha(X, t) / \sigma(X, t)$ is the probability of $u p$; $1-p_{t}$ is the probability of down.

With this set of equations, it is possible to determine the values of up e down for each branch, as well as probability $p_{t}$ for each node, and, thus, to generate the recombinant tree (lattice). However, the values for certain probabilities in each node may be negative; as a result, the authors proposed certain censorship, forcing the values to fit into interval $0 \leq p_{t} \leq 1$.

Substituting $\alpha(X, t)$ and $\sigma(X, t)$ in Equation

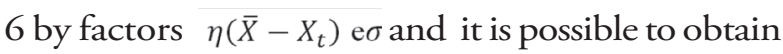
the stochastic differential equation for MRP (Equation 1). In this case, the binomial sequence will be given by:
$X_{t}^{+}=X+\sqrt{\Delta t} \sigma$, the motion upwards (up) Eq. 7 $X_{t}^{-}=X-\sqrt{\Delta t} \sigma$, the motion downwards (down) Eq. 8

Probabilities of censored motion upwards up:

$$
\begin{aligned}
& q_{t}=\left\{\begin{array}{ll}
\frac{1}{2}+\frac{1}{2} \sqrt{\Delta t} \eta \frac{(\bar{X}-X)}{\sigma} & \text { se } 0 \leq q_{t} \leq 1 \\
0 & \text { se } q_{t}<0, \text { is censored } \\
1 & \text { se: } q_{t}>1, \text { is censored }
\end{array} \quad \text { Eq. } 9\right. \\
& 1-q_{t} \text { is the probability of the motion downwards down. }
\end{aligned}
$$

The following is a summary for probabilities:

$$
q_{t}=\max \left\{0, \min \left[1, \frac{1}{2}+\frac{1}{2} \sqrt{\Delta t} \eta \frac{\left(\bar{X}-X_{t}\right)}{\sigma}\right]\right\} \text { Eq. } 10
$$

Probability will vary over time depending on $X(t)$, where $X(t)=\ln \left(x_{t}\right)$. This censored probability produces a model that converges weakly to a mean reversion process.

As an illustration, Figure 1 presents the tree for variable $X$ which varies $\Delta X$ in the interval of time $\Delta t$.

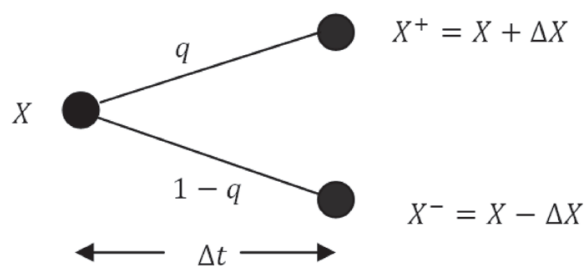

Figure 1. Binomial tree for interval of time $\Delta \mathrm{t}$ Source: Hahn and Dyer (2011)

The variations of $\Delta X$ are as follows: $\Delta X^{+}=\sigma \sqrt{\Delta t}$ and $\Delta X^{-}=-\sigma \sqrt{\Delta t}$. Considering that represents the natural price logarithm, then $\Delta x^{+}=e^{\sigma \sqrt{\Delta t}}$ and $\Delta x^{+}=e^{-\sigma \sqrt{\Delta t}}$.

Thus:

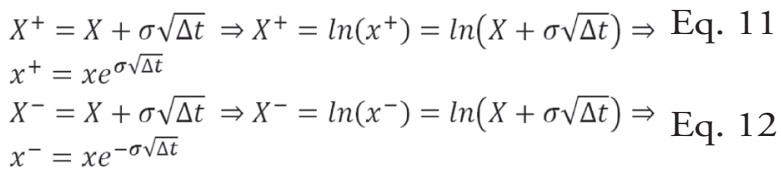

As an illustration, Figure 2 presents the final tree. 


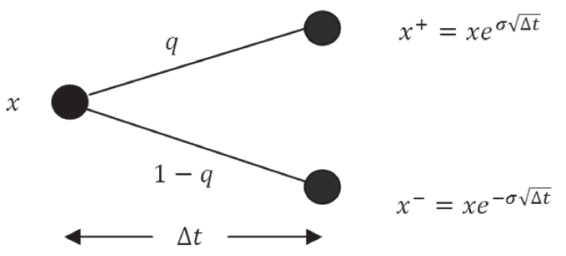

Figure 2. Binomial branch node for prices ()

Source: Hahn and Dyer (2011)

In the assessment of prices, the neutral form of risk to the stochastic process is normally used, so as to be able to discount with the riskfree rate $(r)$. Thus, for MRP, the neutral process to risk is given by the following differential equation

$$
d X(t)=\eta\left(\bar{X}-\frac{\pi}{\eta}-X_{t}\right) d t+\sigma d z_{t} \quad \text { Eq. } 13
$$

Where the risk prize is $\pi=\mu-r$ ( $\mu$ is the total return), and term $\pi / \eta$ is a normalized risk prize which penalizes the price logarithm.

Thus, the probability of risk-adjusted Martingale is given by:

$$
q_{t}=\max \left\{0, \min \left[1, \frac{1}{2}+\frac{1}{2} \sqrt{\Delta t} \eta \frac{\left(\bar{x}-\frac{\pi}{\eta}-x_{t}\right)}{\sigma}\right]\right\} \quad \text { Eq. } 14
$$

\subsection{Bivariate modeling of the Mean Reversion process}

In bivariate modeling, one seeks to combine, in one single tree, two uncertain correlated variables that accompany autoregressive processes. Schwartz and Smith (2000) break down into two factors the natural price logarithm by applying an GBM for the long term and an MRP for the short term. Hahn and Dyer (2011) developed a method for the construction of a bivariate binomial tree that is applicable to the two-factor model of Schwartz and Smith (2000).

Following Hahn and Dyer (2011), the combination of the two variables lead to a quadrinomial tree, as presented in Figure 3.

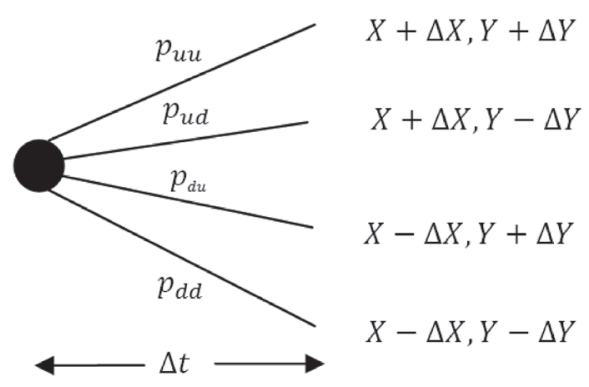

Figure 3. Bivariate tree (quadrinomial) Source: Hahn and Dyer (2011)

In the case of the commodities this paper deals with, we presume that the sugar price logarithm $(X)$ and the ethanol price logarithm (Y) follow an MRP. Thus, $d X(t)=\eta\left(\bar{X}-X_{t}\right) d t+\sigma d z_{X}$ , and $d Y(t)=\eta\left(\bar{Y}-Y_{t}\right) d t+\sigma d z_{Y}$. The relationship between the increases in the two processes is given by $\rho d t=d z_{X} d z_{Y}$, where $\rho$ is the correlation coefficient.

Hahn and Dyer (2011) use the same basic method used by Boyle (1988) to determine the joint probabilities of the processes. These probabilities are given by:

$$
\left\{\begin{array}{l}
p_{u u}=\frac{\Delta_{X} \Delta_{Y}+\Delta_{Y} v_{X} \Delta t+\Delta_{X} v_{Y} \Delta t+\rho \sigma_{X} \sigma_{Y} \Delta t}{4 \Delta_{X} \Delta_{Y}} \\
p_{u d}=\frac{\Delta_{X} \Delta_{Y}+\Delta_{Y} v_{X} \Delta t-\Delta_{X} v_{Y} \Delta t-\rho \sigma_{X} \sigma_{Y} \Delta t}{4 \Delta_{X} \Delta_{Y}} \\
p_{d u}=\frac{\Delta_{X} \Delta_{Y}-\Delta_{Y} v_{X} \Delta t+\Delta_{X} v_{Y} \Delta t-\rho \sigma_{X} \sigma_{Y} \Delta t}{4 \Delta_{X} \Delta_{Y}} \\
p_{d d}=\frac{\Delta_{X} \Delta_{Y}-\Delta_{Y} v_{X} \Delta t-\Delta_{X} v_{Y} \Delta t+\rho \sigma_{X} \sigma_{Y} \Delta t}{4 \Delta_{X} \Delta_{Y}}
\end{array}\right.
$$

Where the increases are $\Delta_{X}=\sigma_{X} \sqrt{\Delta t}$ and $\Delta_{Y}=\sigma_{Y} \sqrt{\Delta t}$. Naturally, the sum of all the joint probabilities has to be equal to 1 , thus $p_{u u}+p_{u d}=1$ and $p_{d u}+p_{d d}=1$. The drift of the processes is given by $v_{X}=\eta_{X}\left(\bar{X}-X_{t}\right)$ and $v_{Y}=\eta_{Y}\left(\bar{Y}-Y_{t}\right)$.

The approach of Hahn and Dyer (2011) combine two recombinant trees, and is based on Nelson and Ramaswamy (1990), in which the probabilities of the prices in each node of the tree are censored, when the reversion leads to values greater than one and smaller than zero. Unfortunately, since there are two factors and, thus, four nodes, censorship cannot be carried 
out directly, as in the case of one single factor. Given this impossibility, Hahn and Dyer (2011) propose applying Bayesian rules to decompose the joint probabilities in the marginal and conditional product of the probabilities: $P(X \cap Y)=P(X) \times P(Y \mid X)$. Thus, the marginal probabilities for $\mathrm{X}$ would be:

$$
\begin{aligned}
& p_{u}=\frac{1}{2}+\frac{1}{2} \frac{v_{x} \Delta_{t}}{\Delta_{x}} \\
& p_{d}=\frac{1}{2}-\frac{1}{2} \frac{v_{x} \Delta_{t}}{\Delta_{x}}
\end{aligned}
$$

As Equações 15 são divididas pelas probabilidades marginais de $X$ (Equações 16) para se obter as probabilidades condicionais (Equações 17). No presente estudo, as probabilidades apresentadas em Hahn \& Dyer (2011) foram corrigidas, pois foram encontrados erros de sinais. A formulação correta, e que foi utilizada neste estudo, é a seguinte:

$$
\left\{\begin{array}{l}
p_{u \mid u}=\frac{\Delta_{X}\left(\Delta_{Y}+\Delta t v_{Y}\right)+\Delta t\left(\Delta_{Y} v_{X}+\rho \sigma_{X} \sigma_{Y}\right)}{2 \Delta_{Y}\left(\Delta_{X}+\Delta t v_{X}\right)} \\
p_{d \mid u}=\frac{\Delta_{X}\left(\Delta_{Y}-\Delta t v_{Y}\right)+\Delta t\left(\Delta_{Y} v_{X}-\rho \sigma_{X} \sigma_{Y}\right)}{2 \Delta_{Y}\left(\Delta_{X}+\Delta t v_{X}\right)} \\
p_{u \mid d}=\frac{\Delta_{X}\left(\Delta_{Y}+\Delta t v_{Y}\right)-\Delta t\left(\Delta_{Y} v_{X}+\rho \sigma_{X} \sigma_{Y}\right)}{2 \Delta_{Y}\left(\Delta_{X}-\Delta t v_{X}\right)} \\
p_{d \mid d}=\frac{\Delta_{X}\left(\Delta_{Y}-\Delta t v_{Y}\right)-\Delta t\left(\Delta_{Y} v_{X}-\rho \sigma_{X} \sigma_{Y}\right)}{2 \Delta_{Y}\left(\Delta_{X}-\Delta t v_{X}\right)}
\end{array}\right.
$$

Equations 15 are divided by the marginal probabilities of $X$ (Equations 16) to obtain conditional probabilities (Equations 17). In this study, the probabilities presented in Hahn and Dyer (2011) were corrected, since signs of errors were found. The correct formula, which was used in this study, is the following:

The quadrinomial tree with joint probabilities is now divided into two stages of probabilities, conditional and marginal, in the same interval $\Delta_{\mathrm{t}}$, for variables $X$ and $Y$, respectively, which is illustrated in Figure 4. As mentioned, following Nelson and Ramaswamy (1990), in this approach the probabilities are also censored so as not to reach values that are negative or greater than one.

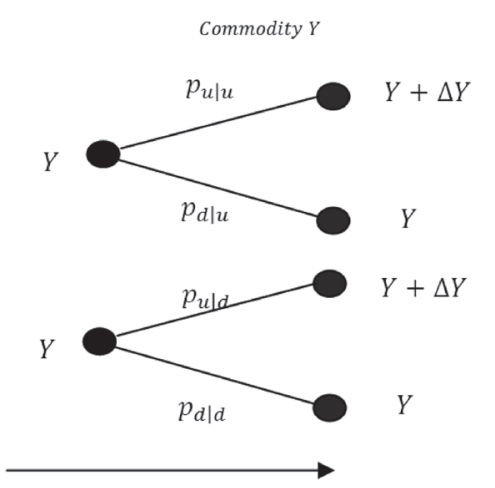

Figure 4. Marginal conditional division of the quadrinomial tree Source: Hahn and Dyer (2011)

In this new formula the following should be adhered to: $p_{u \mid u}+p_{d \mid u}=1$ and $p_{u \mid d}+p_{d \mid d}=1$. For each of the marginal and conditional probabilities, censorship has to be to the necessary extent.
For the Regions studied in this article (Brazil's Northeast and Southeast), there are two differential stochastic equations, one for sugar and one for ethanol:

$$
\begin{gathered}
\text { Northeast }\left\{\begin{array}{l}
d X_{n}(t)=\eta_{a n}\left(\overline{X_{n}}-X_{n t}\right) d t+\sigma_{a n} d z_{t n a} \\
d Y_{n}(t)=\eta_{e n}\left(\overline{Y_{n}}-Y_{n t}\right) d t+\sigma_{e n} d z_{t n e}
\end{array}\right. \\
\text { Southeast }\left\{\begin{array}{l}
d X_{s}(t)=\eta_{a s}\left(\overline{X_{s}}-X_{s t}\right) d t+\sigma_{a s} d z_{t s a} \\
d Y_{s}(t)=\eta_{e s}\left(\overline{Y_{s}}-Y_{s t}\right) d t+\sigma_{e s} d z_{t s e}
\end{array}\right.
\end{gathered}
$$


Where $d z_{\text {tna }}, d z_{\text {tne }}$ are the standard Wiener processes in the Northeast for sugar and ethanol respectively, and $d z_{t s a}$ and $d z_{t s e}$, for the Southeast. The processes are correlated in the following way: $d z_{\text {tna }} d z_{\text {tne }}=\rho_{n} d t$, and $d z_{t s a} d z_{t s e}=\rho_{s} d t$.

According to the results of the regressions of the price logarithms of the series used, the values of correlation coefficients that were found are as follows: $\rho_{n}=0,44435401$ for the Northeast, and $\rho_{s}=0,40727737$ for the Southeast.

\section{Assessment of the switching option}

According to the survey data about the sugar and alcohol production for 2014/15 crops carried out by Brazil's National Supply Company [Companhia Nacional de Abastecimento, CONAB], Table 4 presents the summary of sugarcane production for the Northeast and Southeast regions, dividing the total by sugar and ethanol products.

Table 4

Production and destination of sugarcane in the Northeast and Southeast regions of Brazil

\begin{tabular}{|c|c|c|c|c|c|}
\hline \multirow[b]{2}{*}{ Region/states } & \multicolumn{3}{|c|}{$\begin{array}{c}\text { Sugar and sugarcane industry } \\
(1000 \text { Ton. })\end{array}$} & \multicolumn{2}{|c|}{ \%Total } \\
\hline & Total & Sugar & Ethanol & Sugar & Ethanol \\
\hline Northeast & 55,602 & 30,963 & 24,638 & $55.7 \%$ & $44.3 \%$ \\
\hline Pernambuco (PE) & 14,447 & 10,107 & 4,339 & $70.0 \%$ & $30.0 \%$ \\
\hline Alagoas (AL) & 23,173 & 16,402 & 6.771 & $70.8 \%$ & $29.2 \%$ \\
\hline Total PE and AL & 37,621 & 26,509 & 11,111 & $70.5 \%$ & $29.5 \%$ \\
\hline Southeast & 421,926 & 214,993 & 206,933 & $51.0 \%$ & $49.0 \%$ \\
\hline São Paulo (SP) & 356,283 & 187,369 & 168,914 & $52.6 \%$ & $47.4 \%$ \\
\hline
\end{tabular}

Source: CONAB - MAPA 2014/2015 crops

In this study, the Northeast region is represented by the states of Pernambuco (PE) and Alagoas (AL), which concentrate $67.66 \%$ of the production of sugarcane in this region $(37,621 / 55,602)$. The Southeast region is represented by the state of São Paulo (SP), which harbors $84.44 \%$ of production $(356,286 / 421,926)$. On the other hand, according to the 2012 CONAB report "Profile of Sugar and Ethanol Industry in Brazil" for Crops 2011/2012 ["Perfil do Setor do Açúcar e do Álcool no Brasil" Safra 2011/2012], in the states of Alagoas and Pernambuco operate 46 plants, and in the state of São Paulo there are 169 plants.

With this information, we can determine the quantity $(\mathrm{Q})$ of the annual production of sugarcane by plant in each one of the regions: Northeast (NE) and Southeast (SE).

$$
\begin{gathered}
Q=\frac{\text { Total production }(\text { states in the region) }}{\text { Number of plants }(\text { states } \text { in the region) }} \\
Q_{N E}=\frac{37.621 .000}{46}=817.848 \text { ton } / \text { year } \\
Q_{S E}=\frac{356.283 .000}{169}=2.108 .193 \text { ton } / \text { year }
\end{gathered}
$$

Regarding productivity rates, Neto and Ramon (2002) mention that, on average, in the state of São Paulo, $93.4 \mathrm{~kg}$ of sugar and 76.9 liters of ethanol are obtained per ton of sugarcane. In the Northeast, $92.8 \mathrm{~kg}$ of sugar and 65.7 liters of ethanol are obtained per ton of sugarcane.

Considering the sugar and ethanol productivity rates mentioned by Neto and Ramon (2002), and the quantities for each region ( the Gross Revenue (GR) is as follows: GR = Efficiency $\times \mathrm{Q}$ $\times$ Commodity price. Thus, one can determine the gross revenue of ethanol and of sugar in a standard plant, for the Northeast and Southeast regions.

\section{Gross Revenue Southeast region:}

$$
\begin{aligned}
G R_{\text {Ethanol, }, S E}= & 76,9\left(\frac{L}{t}\right) \times 2.108 .193\left(\frac{t}{\text { year }}\right) \times P_{\text {Ethanol }, S E}\left(\frac{\$ R}{L}\right) \\
= & 162.120 .041 \times P_{\text {Ethanol, SE }} \\
G R_{\text {Sugar }, S E}= & 93,4\left(\frac{K g}{t}\right) \times 2.108 .193\left(\frac{t}{\text { year }}\right) \times P_{\text {Sugar }, S E}\left(\frac{\$ R}{50 \mathrm{Kg}}\right)=3.938 .105 \times P_{\text {Sugar }, S E}
\end{aligned}
$$

\section{Gross Revenue Northeast region:}

$G R_{\text {Ethanol }, N E}=65,7\left(\frac{L}{t}\right) \times 817.848\left(\frac{t}{\text { year }}\right) \times P_{\text {Ethanol, } N E}\left(\frac{\$ R}{L}\right)=53.732 .613 \times P_{\text {Etanol }, N E}$
$G R_{\text {Sugar }, N E}=92,8\left(\frac{K g}{t}\right) \times 817.848\left(\frac{t}{\text { year }}\right) \times P_{\text {Sugar }, N E}\left(\frac{\$ R}{50 ~ K g}\right)=1.517 .926 \times P_{\text {Sugar }, N E}$ 
With the Gross Revenue, one can model the cash flow (CF), which can be represented according to Equation 20.

$$
F C=R B[(1-I C M S)-C V T-C F T] \times(1-I R) \text { Eq. } 20
$$

To determine the components of cash flow some considerations were carried out, such as: total variable cost (TVC) is $20 \%$ of gross revenue (GR), total fixed cost (TFC) is $10 \%$ of
GR, and income tax (IT) is 19\% (Bastian-Pinto et al., 2009). Thus, the cash flows for the two commodities in the two regions can be modeled in two ways: (1) considering that ethanol is produced exclusively, or (2) considering that the sugar/ ethanol mix provided by CONAB (as shown in Table 4) is produced. In the latter case, it is necessary to consider the proportions of sugar and ethanol to multiply by the production, as follows:

\section{CF in the Southeast Region (in R\$1.000):}

(1) CF considering total production of ethanol:

$$
\begin{aligned}
& C F_{\text {Ethanol,SE }}=162.120 P_{\text {Ethanol,SE }}\left[\left(1-I C M S_{\text {Ethanol,SE }}\right)-0,2-0,1\right] \times(1-0,19) \\
& C F_{\text {Ethanol,SE }}=162.120 P_{\text {Ethanol,SE }}\left(0,7-I C M S_{\text {Ethanol,SE }}\right) \times(1-0,19)
\end{aligned}
$$

(2) CF considering sugar/ethanol production mix:

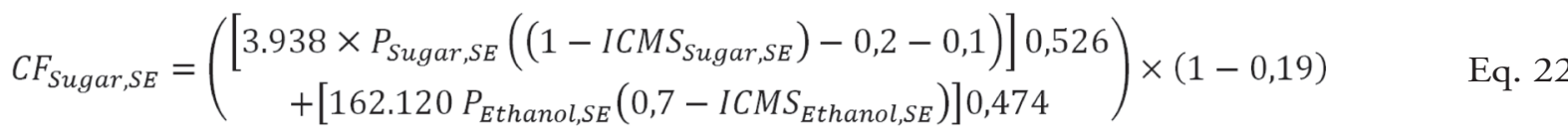

\section{$\mathrm{CF}$ in the Northeast Region (in R\$1.000):}

(3) CF considering total production of ethanol:

$$
\begin{aligned}
& C F_{\text {Ethanol,NE }}=53.732 P_{\text {Ethanol,NE }}\left[\left(1-I C M S_{\text {Ethanol,NE }}\right)-0,2-0,1\right] \times(1-0,19) \\
& C F_{\text {Ethanol,NE }}=53.732 P_{\text {Ethanol,NE }}\left(0,7-I C M S_{\text {Ethanol,NE }}\right) \times(1-0,19)
\end{aligned}
$$

(4) CF considering sugar/ethanol production mix:

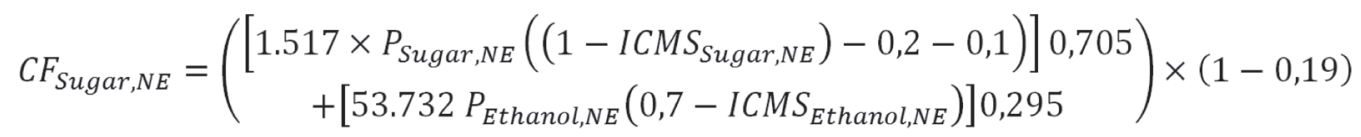

Table 5 presents the ICMS rates for the two commodities in the two regions.

\section{Table 5}

\section{ICMS for the Northeast and Southeast} regions

\begin{tabular}{lcc}
\hline ICMS & Northeast (NE) & Southeast (SE) \\
\hline Ethanol & $25 \%$ & $12 \%$ \\
Sugar & $12 \%$ & $7 \%$ \\
\hline
\end{tabular}

Source: CEPEA (2014)

\section{I Assessment using recombinant trees}

For the construction of recombinant trees, it is necessary to set some parameters. First, it is considered a real ( $r$ ) risk free interest rate equal to $7.25 \%$ p.y.. This value was determined from the average yield of Brazilian Treasury Bills [Letras do Tesouro Nacional, LTN] maturing in 2011, 2012, 2013,2014 . The time horizon used is five years, taking samples every six months $(T=5, n=10$ e $\Delta t=0.5$ ). The risk premium $\pi$ deflated for the sugar and alcohol sector was calculated using the 
Capital Asset Pricing Model (CAPM), based on companies in this sector that trade shares on the BMF\&BOVESPA (an average of approximately $6 \%$ p.a.).
Moreover, using the Equations of Table 2 and the values of the regression coefficients shown in Table 3, the MRP parameters shown in Table 6 are calculated.

Table 6

Parameters of the reversion model for ethanol and sugar in the Northeast and Southeast regions

\begin{tabular}{|c|c|c|c|c|}
\hline \multirow{2}{*}{ Parameter } & \multicolumn{2}{|c|}{ Northeast (NE) } & \multicolumn{2}{|c|}{ Southeast (SE) } \\
\hline & Ethanol & Sugar & Ethanol & Sugar \\
\hline Initial price (July 2014) & 1.5858 & 57.185 & 1.3304 & 47.1785 \\
\hline Long-term average logarithm $(\bar{x})$ & 0.3970 & 4.1170 & 0.2345 & 4.0036 \\
\hline Long-term average $(\bar{P})$ & 1.5148 & 64.9400 & 1.3088 & 59.1207 \\
\hline Volatility $(\sigma)$ & 0.2561 & 0.2999 & 0.3879 & 0.3330 \\
\hline Reversion speed $(\eta)$ & 1.7901 & 0.7979 & 2.1723 & 0.7306 \\
\hline
\end{tabular}

With the calculated parameters, and following the procedure described in section 4.1, one can calculate the binomial tree. Using the censored approach of Nelson and Ramaswamy (1990), the probabilities are calculated by

$$
\operatorname{porq}_{\mathrm{t}}=\max \left\{0, \min \left[1, \frac{1}{2}+\frac{1}{2} \sqrt{\Delta t} \eta \frac{\left(\bar{x}-\frac{\pi}{\eta}-x_{t}\right)}{\sigma}\right]\right\}
$$

To save space in the text, we will not present the illustration of binomial trees generated for the prices and probabilities. They are available from the authors at request.

Based on the simulated prices of sugar and ethanol, sugar cash flows in the Northeast region are calculated using equation 24 over a 5 -year period $(T=5)$. Using the risk-free rate and the censored Martingale probabilities, through the backward (Cox et al., 1979) process, the value of the cash flow is determined for point $t=0$.

Present value, PV, (at point $t=0$ ) of the cash flows for sugar in the Northeast region (NE) is $\mathrm{R} \$ 394.79$ thousand. A similar procedure was used for ethanol in the NE region, and sugar and ethanol in the SE region. In this way, Table 7 shows the present values (PV) for the four approached situations.

We observe that the PV is greater for the Southeat region, for both commodities. For the case of ethanol, the difference between the two regions represents a $242 \%$ difference favorable to the Southeast region. For the case of sugar, on the other hand, the PV difference represents an $177 \%$ percentage.

Table 7

Present values (PV) of the cash flows of the recombinant trees (in $R \$ 1.000$ )

\begin{tabular}{lcc}
\hline Region & Ethanol & Sugar \\
\hline Northeast (NE) & 272.28 & 394.79 \\
Southeast (SE) & 930.42 & 1.093 .25 \\
Difference & 658.14 & 698.46 \\
Difference (\%) & $241.7 \%$ & $176.9 \%$ \\
\hline
\end{tabular}

\subsection{Assessment using bivariate trees}

For the use of quadranomial tree, we begin from the recombinant trees of ethanol prices $(\mathrm{x})$ and of sugar $(y)$. The construction requires more intense computational calculations, for example, at time $t=10$ ( $\mathrm{T}=5$ years) will be obtained for this sample in the quadrinomial tree. Figures 5 and 6 show a fragment of the tree construction process since $n=2$ nodes, to $t=1$ year and $=4$ nodes. In these we can distinguish probabilities at zero value, resulting from having been censored for being negative. Censorship is not carried out directly on the joint probabilities, but on the 
marginal and conditional probabilities, which, when multiplied, result in the joint probabilities.

Table 8 presents, for the two regions studied, the results of the present values (PV) of cash flows for plants that produce ethanol or sugar (sugar/ethanol mix), and the present value (PV) of cash flows for flexible plants.

\section{Table 8}

Results of the present values (PV) of the cash flows, of the binomial and bivariate trees and the value of the Switching Option (in R\$1.000)

\begin{tabular}{lccccccc}
\hline & \multicolumn{2}{c}{ Binomial Tree } & \multicolumn{2}{c}{ Quadrinomial Tree } & \multicolumn{2}{c}{ Value of the Switching Option } \\
\cline { 2 - 7 } & $\begin{array}{c}\text { PV Ethanol } \\
\text { Plant }\end{array}$ & $\begin{array}{c}\text { PV Sugar } \\
\text { Plant }\end{array}$ & $\begin{array}{c}\text { Flex } \\
\text { Plant }\end{array}$ & $\begin{array}{c}\text { \% Dif. } \\
\text { Ethanol } \\
\text { Plant }\end{array}$ & $\begin{array}{c}\text { \% Dif. } \\
\text { Sugar } \\
\text { Plant }\end{array}$ & $\begin{array}{c}\text { From Ethanol } \\
\text { to Flex }\end{array}$ & $\begin{array}{c}\text { From Sugar } \\
\text { to Flex }\end{array}$ \\
\cline { 2 - 8 } (1) Northeast & 272.28 & 394.79 & 432.71 & $\mathbf{5 8 . 9 \%}$ & $\mathbf{9 . 6 \%}$ & 160.43 & 37.92 \\
(2) Southeast & 930.42 & 1.093 .25 & 1.616 .11 & $\mathbf{7 3 . 7 \%}$ & $\mathbf{4 7 . 8 \%}$ & 685.69 & 522.86 \\
Difference (2-1) & 658.14 & 698.46 & 1.183 .40 & & & 525.25 & 484.94 \\
\% Difference & $241 . \%$ & $175.9 \%$ & $273.5 \%$ & & & $327.4 \%$ & $1278.8 \%$ \\
\hline
\end{tabular}

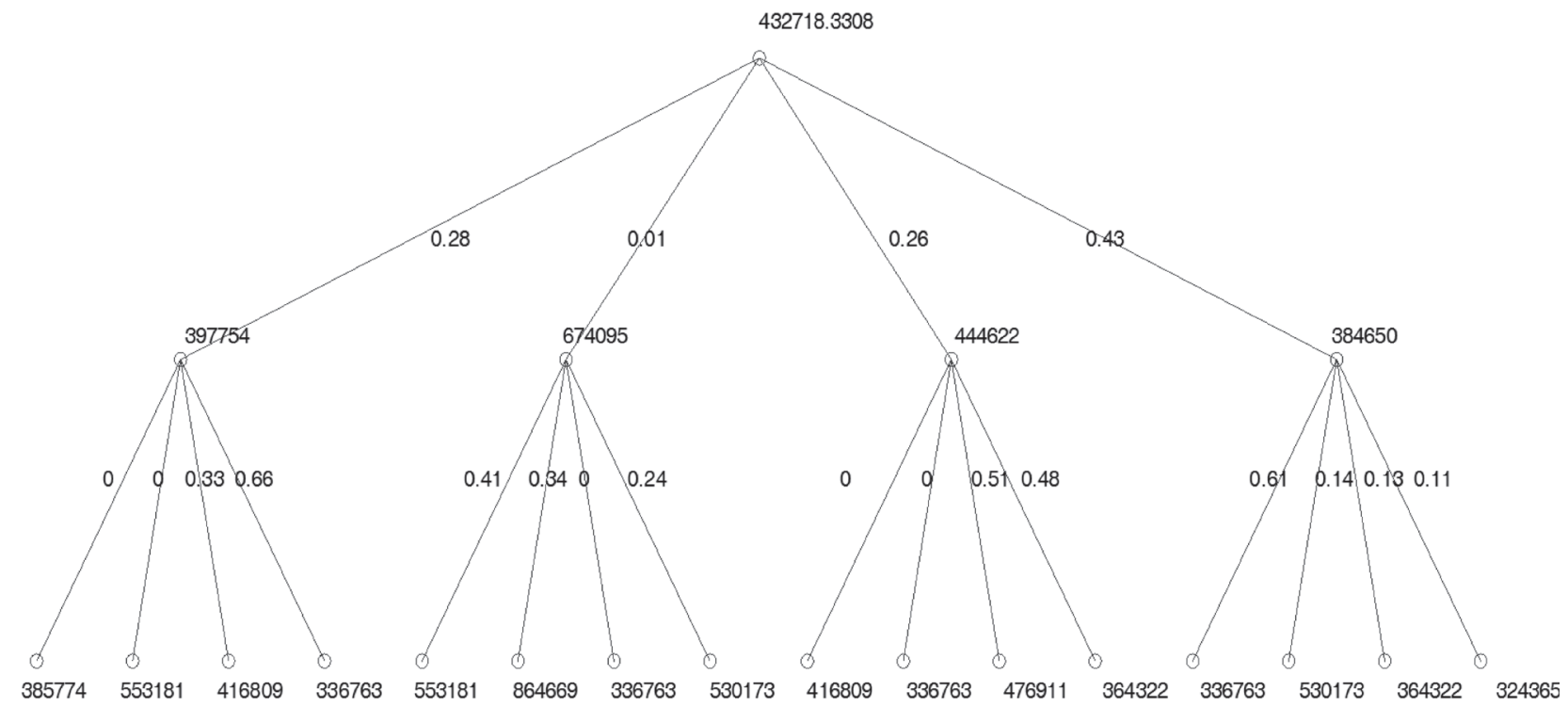

Figure 5. Present value (PV) of the cash flows for the bivariate quadrinomial tree of the Northeast region

The results shown prove that, in the case of the Northeast, the flex plant has a higher value (higher PV) when compared to a plant that produces sugar (sugar/ethanol mix); the difference is $9.6 \%$. As for the comparative case of a plant whose production is focused exclusively on ethanol, the difference from the flex plant is $58.9 \%$, favorable to the latter. In other words, the use of flex plants in Northeast adds R $\$ 160$ million present value to the business when compared to ethanol production, and approximately $\mathrm{R} \$ 38$ million when compared to sugar production. 


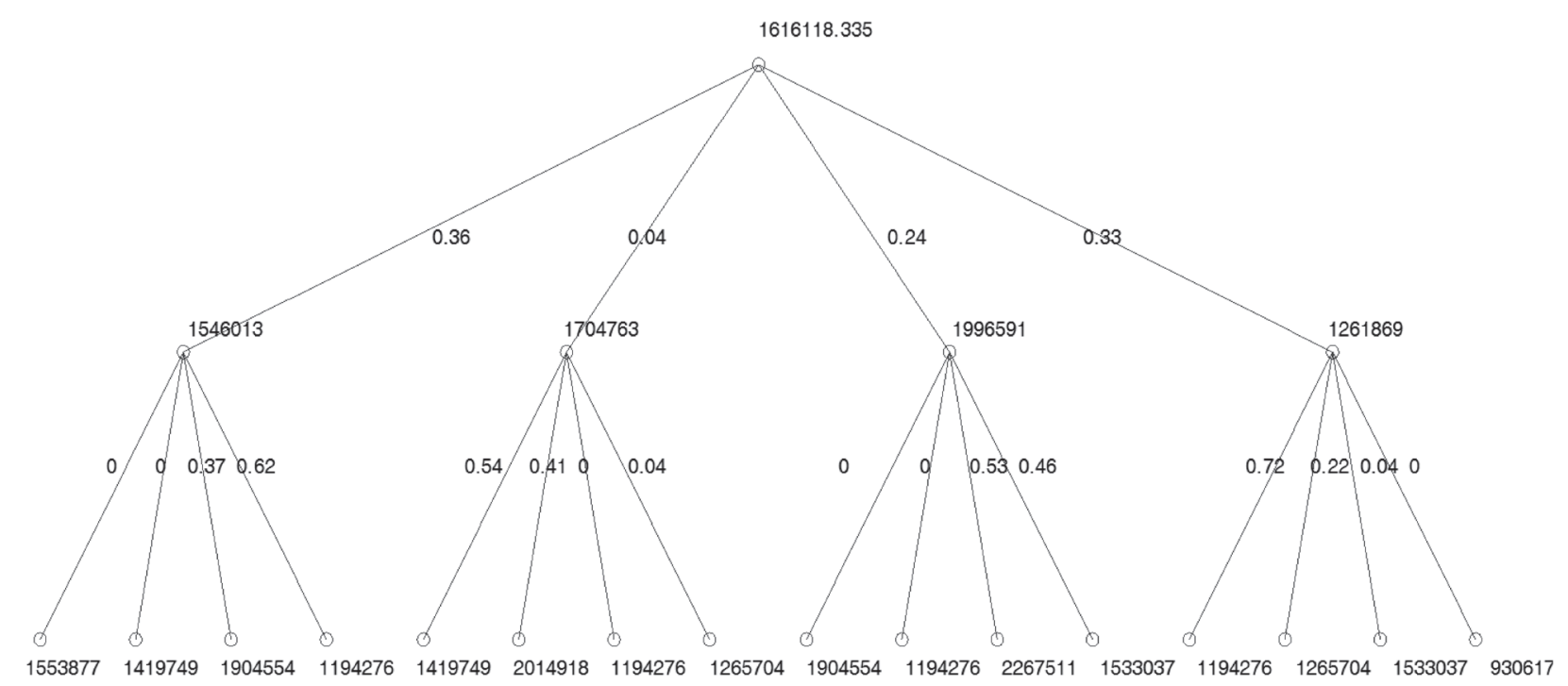

Figure 6. Present value (PV) of the cash flows for the bivariate quadrinomial tree of the Southeast region

In the case of the Southeast, the difference in favor of flex is $73.7 \%$ and $47.8 \%$, when compared to a plant that produces only ethanol and one that produces sugar (sugar/ethanol mix), respectively. This means that the decision to use the flex plant increases the present value of the business in $\mathrm{R} \$ 686$ million when compared to ethanol production, and $\mathrm{R} \$ 522$ million, when compared to sugar production.

These gains, both in the Northeast and in the Southeast, occur despite the greater efficiency in sugar production compared to ethanol (note the efficiency parameters in the equations that compute the Gross Revenue). This means that the investment in flexibility for the construction of a flex plant is advantageous to the levels of the mentioned gains. That is, the additional investment in the flex plant compared to a nonflex plant should not be smaller than the gain derived from the operation of changing the production of one product to another throughout the plant's productive life.

After identifying the gains from operating flexible plants, two aspects should be highlighted. The first one refers to the investing agent: investing in inflexible systems means neglecting this gain (i.e. "leaving money on the table"). The second one refers to the regulating agent: a flexible plant results in greater gains for the investor and, therefore, more tax collection (ceteris paribus), and this means that there is room for tax policies aimed at encouraging the construction of flexible systems. In short, the possibility of increasing flexibilization depends on the investor's knowledge of potential gains and incentives for the construction of such systems by regulating authorities.

In the case of the value of the flexibility (switching) option, we observed that this value in the Southeast region is more significant when compared to the Northeast. This was to be expected, because the comparative advantages (smaller ICMS and greater production) are better in this region. For both regions, Table 8 shows that flexibility adds a significant value. We observed that, in the case of ethanol, the switching option value is $327.4 \%$ greater in the Southeast than in the Northeast. The same applies to the case of sugar, where, for the Southeast, this option's value is $1278 \%$ greater than in the Northeast.

\section{Conclusions}

Biofuels such as ethanol are emerging from increasing concern about issues such as the developing technologies that are an alternative to fossil fuels - that are cleaner and present 
clean production mechanisms. The potential for production and the increase in demand for ethanol make sugarcane one of the most important crops in the current Brazilian agribusiness scenario. Sugarcane is not just another national agricultural product, but the most important source of biomass energy, because of the potential of the sugar and ethanol industry in Brazil.

According to the aspects described and the results generated in the development of this article, we can conclude mainly that the value of the switching option in the sugar and alcohol sector is associated with determining factors. First, the production of sugarcane by region, highlighting the Southeast region which, according to the $2014 / 15$ crops, produces $421,926,000$ tons of sugarcane, against 55.602 million tons in the Northeast (sugarcane production from the Northeast region adds up to $38 \%$ of the Southeast region production). Another important factor is ethanol's efficiency ratio in the Southeast, which is $76.9 \mathrm{~L} /$ ton, while in the Northeast it is only 65.7 L/ton. On the other hand, the ICMS tax affects the sugar and alcohol industry revenue in a significant way; the Southeast has greater tax incentives (ICMS 12\% for ethanol and 7\% for sugar), while in the Northeast the rates are higher (25\% ICMS for ethanol and 12\% for sugar).

By modeling commodity prices through MRP and using quadrinomial trees with censored probabilities, we determined the value of the switching option embedded in plants with flexible production (flex plants); according to the values that were found, we conclude that factors such as the level of production and the tax burden, combined with commodity prices, affect the value of the switching option in a relevant way, and that flex plants are always more advantageous than plants that only produce ethanol or sugar. In the study results we found that the plants in the Southeast have a higher cash flow present value than the plants located in the Northeast, mainly due to their higher production level and to the considerably lower taxation they face. Thus, these components must not be disregarded when performing the analysis of the value of the flexibility option for flex-type plants in the Brazilian sugar and alcohol sector.

One of the contributions of the study, as proven by the results, are the implications for policies focused on this sector. The results show that it is more attractive for producers to invest in flexible plants. Thus, they can take advantage of ethanol production and of sugar production, according to the convenience of product prices. Thus, a flexible plant will remain in operation for a longer period of time, and always operate in an optimal situation in terms of revenue. Consequently, it will contribute more taxes both on state and federal level. Therefore, the regulators will have more space to prepare tax incentive policies for the construction of flexible systems. This is important, especially for the Northeast region, where the tax burden is high when compared to the Southeast.

\section{Note}

1 The authors would like to thank the two anonymous reviewers for their suggestions, which helped improve the quality of this study. The remaining errors or omissions are our responsibility.

\section{References}

Aiube, F. A. L., \& Samanez, C. P. (2014). On the comparison of Schwartz and Smith's two-and three-factor models on commodity prices. Applied Economics, 46(30), 3736-3749.

Balcombe, K.; Rapsomanikis, G. (2008) Bayesian Estimation and selection of nonlinear vector correction models: the case of the sugar-ethanol-oil nexus in Brazil. American Journal of Agricultural Economics. 90(3) August: 658-668

Barros, G. S. C, \& Moraes, M.A. F. D (2002). A desregulamentação do setor sucroalcooleiro. Revista de Economia Política, vol 22, n. 2 (86), April-June. 
Bastian-Pinto, C., Brandao, L., \& Hahn, W. J. (2009). Flexibility as a source of value in the production of alternative fuels: The ethanol case. Energy Economics, 31(3), 411-422. doi: DOI 10.1016/j.eneco.2009.02.004

Bessembinder, H., Cougehnour, J., Seguin, P., \& Smoller, M. (1995). Mean reversion in equilibrium asset prices: Evidence from futures term structure. Journal of Finance, vol 50(1), 361-375.

Black, F., \& Scholes, M. (1973). The Pricing of Options and Corporate Liabilities. The Journal of Political Economy, 81(3), 637-654.

Boff H. P. (2011) Modeling the Brazilian Ethanol Market: How Flex-Fuel Vehicles are Shaping the Long Run Equilibrium, China-USA Business Review, 10 (4), 245-264.

Boyle, P. A. (1988). A Lattice Framework for Option Pricing with Two State Variables. Journal of Financial and Quantitative Analysis, 23(1), 1-12.

Cavalcante, H. P. M. (2010). Aspectos relativos ao etanol brasileiro e as barreiras não-tarifárias à sua importação, jurídicos Direto E-nergia, Ano II, vol 2, January-July. Available at: <http://periodicos. ufrn.br/direitoenergia/article/viewFile/4238/3474>

CEPEA. Available at: <http://www.cepea.esalq.usp. br>. Access on: 02 de maio de 2014.

COSENCANA-SP. Available at: <http://www. consecana.com.br/>. Access on: 20 de maio de 2106.

Cox, J. C., Ross, S. A., \& Rubinstein, M. (1979). Option pricing: A simplified approach. Journal of Financial Economics, 7(3), 229-263. doi: Doi: $10.1016 / 0304-405 x(79) 90015-1$

Dixit, A. K., \& Pindyck, R. S. (1994). Investment under Uncertainty. Princeton: Princeton University Press.

FGV-IBRE. Available at: <http://portalibre.fgv.br> Access on: 09 de maio de 2014.
Hahn, W. J. (2005). A Discrete-Time Approach for Valuing Real Options with Underlying MeanReverting Stochastic Processes. (PhD Dissertation), The University of Texas, Austin.

Hahn, W. J., \& Dyer, J. S. (2011). A Discrete Time Approach for Modeling Two-Factor MeanReverting Stochastic Processes. Decision Analysis, 8(3), 220-232. doi: 10.1287/deca.1110.0209

Lima, N. C., De Oliveira, S. V. W. B., De Oliveira, M. M. B., \& Queiroz, J. V. (2013). Caracterização da demanda do combustível etanol hidratado no mercado brasileiro. Gestão Contemporânea (13), 25-44.

Macedo, I. C. (2007). Situação atual e perspectivas do etanol, Estudos Avançados, 21(59). Available at: http://www.scielo.br/pdf/ea/v21n59/a11v2159.pdf

Melo, A. S.; Sampaio, Y. (2016) Uma Nota Sobre o Impacto do Preço do Açúcar, do Etanol e da Gasolina na Produção do Setor Sucroalcooleiro. Revista Brasileira de Economia. v. 70 n. 1 / p. 61-69.

Moraes, M. A. F. D (1999). A desregulamentação do setor sucroalcooleiro brasileiro. Tese de doutorado, Departamento de Economia, Universidade de Sáo Paulo.

Nascimento, C. C (2012). O valor da opção do carro Flex por região geográfica do Brasil: uma aplicação da Teoria das Opções Reais com Movimento de Reversão à Média. Rio de Janeiro, RJ, Masters' Dissertation. PUC-Rio.

Nelson, D. B., \& Ramaswamy, K. (1990). Simple Binomial Processes as Diffusion Approximations in Financial Models. Review of Financial Studies, 3(3), 393-430.

Neto, V. C., \& Ramon, D. (2002). Análises de opçôes tecnológicas para projetos de co-geração no setor sucro-alcooleiro. Brasília, $D F$.

Pindyck, R.S. (1999). The long-run evolution of energy prices. The Energy Journal, vol 20 number 2, 1-27. 
Samanez, C. P., \& Costa, L. d. A. (2014). Avaliação de opçóes de swing em contratos de gás natural usando um modelo de dois fatores. Production Journal, 24(4), 760-775.

Samanez, C. P., Ferreira, L. d. R., \& Do Nascimento, C. C. (2014). Avaliação da opção de troca de combustível no carro brasileiro flex: um estudo por regiáo geográfica usando teoria de opções reais e simulação estocástica. Production, 24(3), 628-643.

Schwartz, E. S. (1997). The stochastic behavior of commodity prices: Implications for valuation and hedging. The Journal of Finance, 3(52), 923-973.
Schwartz, E., \& Smith, J. E. (2000). ShortTerm Variations and Long-Term Dynamics in Commodity Prices. Management Science, 46(7), 893-911. doi: 10.1287/mnsc.46.7.893.12034

Tourinho, O. A. F. (1979). The valuation of reserves of natural resources: An option pricing approach. PhD thesis, University of California, Berkeley, 1979.

Trigeorgis, L. (1996). Real Options: Managerial flexibility and strategy in resource allocation, MIT Press.

\section{About the authors:}

1. David Eduardo Lopez Pantoja, MSc. in Production Engineering, PUC-RJ, Brazil.

E-mail: davidlopezpantoja@gmail.com.

2. Carlos Patricio Mercado Samanez (in memoriam), PhD in Management, Getúlio Vargas FoundationSP, Brazil.

3. Javier Gutierrez Castro, PhD in Production Engineering, UTFPR, Brazil.

E-mail: jgutierrezcastro@gmail.com.

4. Fernando Antonio Lucena Aiube, PhD in Production Engineering, PUC-RJ, Brazil.

E-mail: faiube@gmail.com.

\section{Contribution of each author:}

\begin{tabular}{|c|c|c|c|c|}
\hline Contribution & $\begin{array}{l}\text { David Eduardo } \\
\text { Lopez Pantoja }\end{array}$ & $\begin{array}{c}\text { Carlos Patrício } \\
\text { Mercado Samanez }\end{array}$ & $\begin{array}{l}\text { Javier Gutierrez } \\
\text { Castro }\end{array}$ & $\begin{array}{l}\text { Fernando Antonio } \\
\text { Lucena Aiube }\end{array}$ \\
\hline 1. Definition of research problem & $\sqrt{ }$ & $\sqrt{ }$ & & \\
\hline $\begin{array}{l}\text { 2. Development of hypotheses or research } \\
\text { questions (empirical studies ) }\end{array}$ & $\sqrt{ }$ & $\sqrt{ }$ & & \\
\hline $\begin{array}{l}\text { 3. Development of theoretical propositions } \\
\text { (theoretical Work ) }\end{array}$ & $\sqrt{ }$ & $\sqrt{ }$ & & \\
\hline 4. Theoretical foundation/ Literature review & $\sqrt{ }$ & $\sqrt{ }$ & $\sqrt{ }$ & $\sqrt{ }$ \\
\hline 5. Definition of methodological procedures & $\sqrt{ }$ & $\sqrt{ }$ & & \\
\hline 6. Data collection & $\sqrt{ }$ & & & \\
\hline 7. Statistical analysis & $\sqrt{ }$ & $\sqrt{ }$ & $\sqrt{ }$ & $\sqrt{ }$ \\
\hline 8. Analysis and interpretation of data & $\sqrt{ }$ & $\sqrt{ }$ & $\sqrt{ }$ & $\sqrt{ }$ \\
\hline 9. Critical revision of the manuscript & $\sqrt{ }$ & $\sqrt{ }$ & $\sqrt{ }$ & $\sqrt{ }$ \\
\hline 10. Manuscript Writing & $\sqrt{ }$ & $\sqrt{ }$ & $\sqrt{ }$ & $\sqrt{ }$ \\
\hline 11. Other (please specify which) & & & & \\
\hline
\end{tabular}

